\section{Mud Volcanoes of Minbu, Upper Burma.}

THE accompanying photographs of the mud volcanoes of Minbu in Upper Burma may be of interest to readers of Nature. Minbu is on the Irrawaddy, near the oil-ficlds of Yonangyaung. 'The volcanoes are small hillocks of grey mud or clay. The hills bogin as holes, from which mud oozes and forms continually growing cones. Inflammable gasos are also cxuded with the mud. The local people associate superstitious ideas with the volcanic activity.

Fig. 1 is a general view of the mud volcanoes. Fig.

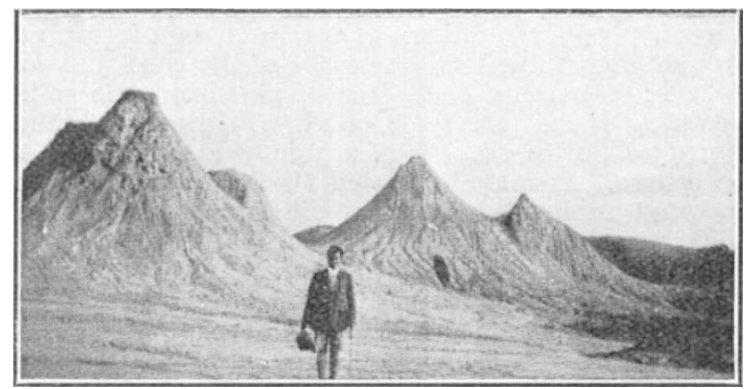

Fia. 1.-Mud volcanoes at Minbu.

2 shows instantanoous stagos of bubbles of mud in the crater of tho largest voluano. The crater is about $5 \mathrm{ft}$. across; and the bubbles in Fig. 2 were about
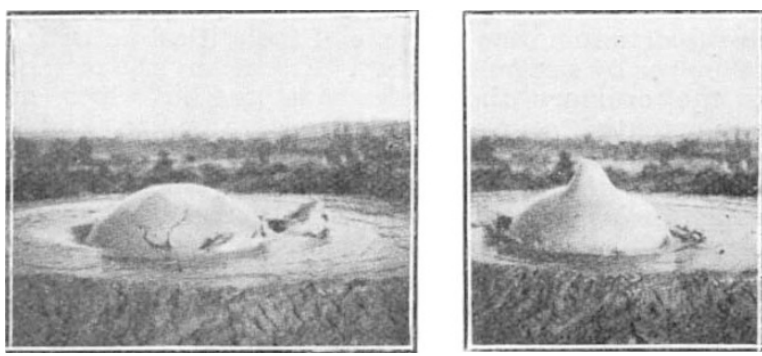

FıG. 2.-Stages in bubble formation.

$1 \frac{1}{2} \mathrm{ft}$. in diameter. 'The mud is thick, but cold, with a faint odour suggestive of crude petroleum.

Alipore, Calcutta, India.

V. V. SOHONI.

\section{Flame and Combustion.}

Wr want to thank Prol. Armstrong for his breezy rovicw of our book in NaTuRE of sept. 24 and his suggestions for improving our brains, Before putting on the 'thinking cap,' however, we would like to ask him why, in discussing flame-reactions, he asscrts that we "ignore the prime fact, that the heat of com. bustion of carbonic oxide is below that of hydrogen; ... It cannot, therefore, bo oxidiscd by steam"? For, in our 'nursery' days, we were taught that it is the other way round, and that, volume for volums, hydrogen burning to steam gives out about 16 per cent. less energy than carbonis oxide burning to carbon dioxido; also that the change from the system $\mathrm{CO}+\mathrm{H}_{2} \mathrm{O}$ (steam) to the system $\mathrm{CO}_{2}+\mathrm{H}_{2}$ is cxothermic. If, as Prof, Armstrong says, we are wrong, wo havo sinned in such good company as Berthelot, Julius Thomsen, and indeod every other investigator of heats of combustion. On the other hand, if we are right, does not the 'snag' in his combustion theory thus stand self-revealed? Is there, indeod, any evidenco that not 'hydrone' (steam) but something much more complex and 'hydronolic' (water) is formed in flarues ?

Doubtless Prof. Armstrong will dismiss all this as of no consequence, as he does our spectroscopic evidence, narnely, that the flame spectra of dry $\mathrm{CO}$ air explosions at high initial pressures show no vestiges of 'steam lines.' We regard it as conclusive against his theory. Such boing the case, we do not wonder that he wants our laboratories to be shut up whilst he settles the matter for us intellectually.

William A. BONe.

D. T. A. TOWNEND.

THE heats of formation given by Thomsen are:

$$
\begin{aligned}
& \mathrm{IT}_{2}, \mathrm{O}=68360 \\
& \mathrm{CO}, \mathrm{O}=67960
\end{aligned}
$$

$X$ take into account the heat of formation of water, not that of hydrono (stcam), between which there is a profound difference. Prof. Bone already has kindly given me credit for carrying my imagination far in these matters : I would ask him to try to follow me ere we begin to dispute. H. E. Armstrong.

\section{High-Frequency Interruption of Light.}

Ar my suggestion, Messrs. Adam Hilger and $\mathrm{Co}$. havo made the experiment of passing a beam of light through a quartz piezo-oloctric resonator placed between crossed Nicol prisms.

When the crystal plate is excited to resonant vibration by an applied oscillating voltage from a valvo-circuit, light is strongly transmitted, and examination of this light in a rotating mirror shows that it consists of regular flashes, tho frequency being apparently double that of the electrical oscillations. The effect is best obtained when the light is passed in a direction parallel to that of the optic axis or, to avoid rotatory dispersion of white light, at an angle of $22^{\circ}$ with this axis. An attempt to photograph the flashes passing through a crystal oscillating at 144 kilocycles por second on a high-speod film camera was unsuccessful, but faint striæ were obtainod on a plate moved slowly across the beam after resolution.

Any bright source of light may be used, the colour of the flashos of light from a white source changing, howover, as either Nicol is rotated. With monochromatic light the interruption is probably complete.

It would seem probable that tho high frequency and perfect regularity of the flashes -there scoms no reason why ton million per second, or more, should not be possible render this method superior to all others, such as the toothed wheel of Fizeau, the rotating mirror of Foucault, or even the so-called 'Kerr' cell recently employed for television--which have hitherto boen used to obtain rapid internittence in a beam of light.

The application to a variety of physical determinations such as the measurement of light-velocity, exact comparison or even absolute determination of crystal frequencies, production of a time-base on a moving film, ote., is obvious, and the method may also prove valuable in telegraphic transmission of pictures and in the photophone. The intensity of the flashes can roadily be modulated by modulating tho oscillating voltage applied to the crystal.

I wish to thank the management of Messes. Adam Hilger and Co. for so kindly giving facilities for the experiments, and Messis. Underhill and Brown of their staff for the interest and skill which made the demonstration of them a success. KERR GRANr.

No. 3025, VoL. 120] 